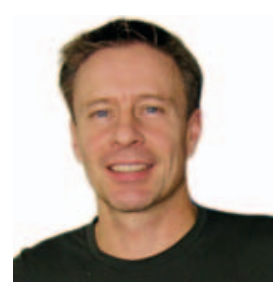

Prof. Dr. Olaf Strauß olaf.strauss@charite.de
Beiträge zu

\section{Möglichkeiten in der Anti-VEGF-A-Therapie}

\author{
ausgewählt und kommentiert von \\ O. Strauß (Berlin)
}

Die Neutralisation vom VEGF-A hat sich in der Behandlung der feuchten altersbedingten Makuladegeneration (AMD) durchgesetzt. Zur Verbesserung der Therapie werden antiVEGF-A-kombinierte Therapieansätze beforscht, die zusätzliche pathologische Mechanismen unterbinden. In klinischen Studien wie Fovista [1] oder ONYX [2] wird versucht, die Stabilität neuer Gefäße zu vermindern.

Komplementfaktoren wären weitere mögliche effektive Targets. Die Bedeutung des Komplements zeigt sich am CD46, einem von fast jeder Zelle exprimierten Rezeptor, der verhindert, dass das Komplementsystem die eigenen Zellen angreift. In der Studie von Lyzogubov et al. zeigt eine CD46 Knock-out-Maus alle Symptome der AMD, vor allem geographische Atrophie. Wie ein Komplement das retinale Pigmentepithel (RPE) schädigt, konnten die Autoren Brandstetter et al. zeigen. Das Komplementprodukt C5a «primed» RPE Zellen zur Ausbildung eines Inflammasoms, das die RPE-Zellfunktionen in einem entzündlichen Phänotyp ändert. Änderungen der Zellfunktion durch Inflammasome sind durch einen Regulator des Zellmetabolismus, den mTOR (mammalian Target of Rapamycin) verknüpft. Tatsächlich konnten Ma et al. zeigen, dass mTOR-Hemmung die chorioidale Neovaskularisation im Mausmodell effektiv reduzieren kann.

Fazit für Klinik ist, dass die Kombinationstherapie erhebliche Verbesserungen der bisherigen Anti-VEGF-A-Therapie ermöglicht, wie aktuelle klinische Studien zeigen. Untersuchungen zu Mechanismen der lokalen Komplement-Aktivierung zeigen neue Targets auf.

\section{Referenzen}

1 A phase 3 safety and efficacy study of Fovista ${ }^{\circ}$ (E10030) intravitreous administration in combination with Lucentis ${ }^{\circledast}$ compared to Lucentis ${ }^{\star}$ monotherapy. ClinicalTrials.gov Identifier: NCT01944839.
2 Anti-angiOpoeitin 2 plus anti-vascular eNdothelial growth factor as a therapY for neovascular age related macular degeneration: evaluation of a fiXed combination intravitreal injection (ONYX). ClinicalTrials.gov Identifier: NCT02713204.

\section{KARGER}

Fax +497614520714 information@karger.com www.karger.com (c) 2016 S. Karger GmbH, Freiburg
Prof. Dr. Olaf Strauß

Klinik für Augenheilkunde

Charité - Universitätsmedizin Berlin

Augustenburger Paltz 1, 1353 Berlin, Deutschland

olaf.strauss@ charite.de 
Lyzogubov VV, Bora PS, Wu X, Horn LE, de Roque R, Rudolf $\mathrm{XV}$, Atkinson JP, Bora NS: The complement regulatory protein CD46 deficient mouse spontaneously develops dry-type age-related macular degeneration-like phenotype. Am J Pathol 2016;186:2088-2104.

In the mouse, membrane cofactor protein (CD46), a key regulator of the alternative pathway of the complement system, is only expressed in the eye and on the inner acrosomal membrane of spermatozoa. We noted that although Cd46-/-mice have normal systemic alternative pathway activating ability, lack of CD46 leads to dysregulated complement activation in the eye, as evidenced by increased deposition of C5b-9 in the retinal pigment epithelium (RPE) and choroid. A knockout of CD46 induced the following cardinal features of human dry age-related macular degeneration (AMD) in 12-monthold male and female mice: accumulation of autofluorescent material in and hypertrophy of the RPE, dense deposits in and thickening of Bruch's membrane, loss of photoreceptors, cells in subretinal space, and a reduction of choroidal vessels. Collectively, our results demonstrate spontaneous agerelated degenerative changes in the retina, RPE, and choroid of Cd46-/-mice that are consistent with human dry AMD. These findings provide the exciting possibility of using Cd46-/-mice as a convenient and reliable animal model for dry AMD. Having such a relatively straight-forward model for dry AMD should provide valuable insights into pathogenesis and a test model system for novel drug targets. More important, tissue-specific expression of CD46 gives the Cd46-/-mouse model of dry AMD a unique advantage over other mouse models using knockout strains.

Brandstetter C, Holz FG, Krohne TU: Complement component C5a primes retinal pigment epithelial cells for inflammasome activation by lipofuscin-mediated photooxidative damage. J Biol Chem 2015;290:31189-31198.

Complement activation, oxidative damage, and activation of the NLRP3 inflammasome have been implicated in retinal pigment epithelium (RPE) pathology in age-related macular degeneration (AMD). Following priming of RPE cells, the NLRP3 inflammasome can be activated by various stimuli such as lipofuscin-mediated photooxidative damage to lysosomal membranes. We investigated whether products of complement activation are capable of providing the priming signal for inflammasome activation in RPE cells. We found that incubation of primary human RPE cells and ARPE-19 cells with complement-competent human serum resulted in up-regulation of C5a receptor, but not C3a receptor. Furthermore, human serum induced expression of pro-IL- $1 \beta$ and enabled IL- $1 \beta$ secretion in response to lipofuscin phototoxicity, thus indicating inflammasome priming. Complement heatinactivation, C5 depletion, and C5a receptor inhibition suppressed the prim- ing effect of human serum whereas recombinant $\mathrm{C} 5 \mathrm{a}$ likewise induced priming. Conditioned medium of inflammasome-activated RPE cells provided an additional priming effect that was mediated by the IL-1 receptor. These results identify complement activation product $\mathrm{C} 5 \mathrm{a}$ as a priming signal for RPE cells that allows for subsequent inflammasome activation by stimuli such as lipofuscin-mediated photooxidative damage. This molecular pathway provides a functional link between key factors of AMD pathogenesis including lipofuscin accumulation, photooxidative damage, complement activation, and RPE degeneration and may provide novel therapeutic targets in this disease.

\section{Ma J, Sun Y, López FJ, Adamson P, Kurali E, Lashkari K:} Blockage of PI3K/mTOR pathways inhibits laser-induced choroidal neovascularization and improves outcomes relative to VEGF-A suppression alone. Invest Ophthalmol Vis Sci 2016;57:3138-3144.

Purpose: Choroidal neovascularization (CNV) is a major cause of visual loss with age-related macular degeneration (AMD). We evaluated whether blockade of phosphatidyl-inositol-3-kinase (PI3K) and the mammalian target of rapamycin (mTOR), by impairing VEGF-A and other growth factor receptors like platelet-derived growth factor (PDGF), would reduce laser-induced CNV in mice.

Methods: Choroidal neovascularization lesions were induced in C57BL/6 mice. Two groups of mice received oral GSK2126458 (3 mg/kg) or vehicle for 14 days following laser, whereas three groups were treated with GSK2126458 ( $6 \mu \mathrm{g} / \mathrm{eye})$, aflibercept ( $2 \mu \mathrm{L} / \mathrm{eye})$, or vehicle intravitreally on days 0 and 7 after laser. Vascular leakage was measured by fluorescein angiography (FA) on day 14. Choroidal neovascularization membranes were evaluated on choroidal flat mounts following FITC-dextran perfusion, as well as ED1 and isolectin B4 (IB4) immunohistochemistry.

Results: Oral and intravitreal (IVT) GSK2126458 reduced leakage and area of CNV lesions. Greater probability of leaking lesions ( 60\%; $\mathrm{P}<0.05)$ was observed in both vehicle groups. Fluorescein isothiocyanate-dextran-labeled total CNV burden area (total lesion area/eye) was reduced $\sim 67 \%(\mathrm{P}<0.05)$ and 35\% $(\mathrm{P}=0.0528)$ after oral and IVT GSK2126458 administration. GSK2126458 treatment reduced lesion size by $~ 80 \%(\mathrm{P}<0.05)$ and 50\% $(\mathrm{P}<$ $0.05)$ for oral and IVT control groups. Aflibercept did not alter lesion size ( $\sim 27 \%$ reduction).

Conclusions: Phosphatidyl-inositol-3-kinase/mTOR is involved in laserinduced CNV angiogenic processes. GSK2126458 effectively reduces CNV size and leakage. Choroidal neovascularization size following IVT GSK2126458 was smaller than after oral administration. Therefore, inhibition of PI3K/mTOR pathways may be more effective due to blockade of action of multiple growth factors. 